\title{
Variación de las características mecánicas de armaduras de alta ductilidad B500SD en función de su grado de corrosión
}

\section{Mechanical properties variation of B500SD high ductility reinforcement regarding its corrosion degree}

\author{
A. Cobo ${ }^{(*)}, \underline{E}$ Moreno $^{(*)}$, M. F. Cánovas ${ }^{(*)}$
}

Recepción/Received: 28-VII-10

Aceptación/Accepted: 1-II-11

Publicado online/Online publishing: 9-V-11

RESUMEN

Los efectos de la corrosión sobre las armaduras se manifiestan por la pérdida de sección y la variación de las propiedades mecánicas relacionadas con la ductilidad. En este trabajo se han ensayado a tracción 96 barras de acero B500SD que previamente se han sometido a niveles variables de corrosión. Los resultados muestran que los alargamientos de las barras disminuyen y el cociente entre la tensión máxima y el límite elástico aumenta conforme el nivel de corrosión avanza. A partir del estudio del efecto de entalla y de la distinta constitución metalográfica del acero a nivel de sección debido a su procedimiento de fabricación se pueden explicar los fenómenos anteriores.

Palabras clave: corrosión, armadura, ensayo de tracción, ductilidad, hormigón.
SUMMARY

Corrosion effects on reinforcement become evident in the bar section reduction and in the variation of mechanical properties related to ductility. In this research work, 96 B500SD steel bars, previously subjected to different corrosion variables, have been tested. Results show that the elongation of the bars diminishes and the ratio between the maximum tensile stress and the elastic limit increases as the corrosion degree advances. These phenomena can be explained by studying the necking effect and the different steel composition through the manufacture process.

Keywords: corrosion, reinforcement, tensile test, ductility, concrete.

\section{INTRODUCCIÓN}

Desde su inicio, las estructuras de hormigón armado (EHA) se plantearon con una duración prácticamente ilimitada. Sin embargo, la experiencia ha demostrado que, debido a procesos de naturaleza mecánica, física, química

\section{INTRODUCTION}

Initially, reinforced concrete structures (RCS) were thought to last a practically unlimited time period. However, experience has shown that due to mechanical, physical or biological reasons, concrete

(*) Universidad Politécnica de Madrid (Madrid, España).

Persona de contacto/Corresponding author: esther.moreno@upm.es 
o biológica, el hormigón se deteriora y las armaduras pueden sufrir procesos de corrosión.

La corrosión de las armaduras es el principal factor de deterioro de las EHA cuando una vez destruida su capa pasiva existe suficiente humedad (1-3). La consecuencia es la drástica reducción de la vida útil de las EHA, hasta valores muy por debajo de los previstos inicialmente en proyecto $(4,5)$. Una vez desencadenado el proceso, la rehabilitación de EHA es muy costosa $(6,7)$. Sin embargo, su prevención en las etapas de diseño y ejecución supone un coste muy inferior (8).

Los efectos de la corrosión sobre las EHA se manifiestan en tres vertientes: sobre el hormigón, sobre el acero y sobre el sistema hormigón armado.

Los productos de corrosión son más voluminosos que el material base, las tensiones de tracción generadas en el hormigón del recubrimiento como consecuencia de la presión generada por los óxidos, producen su fisuración y desprendimiento. Pequeñas penetraciones de corrosión, del orden de $100 \mu \mathrm{m}$, son capaces de producir la fisuración del recubrimiento (9-11). La corrosión de la armadura afecta a su comportamiento adherente por la variación de la interfase existente entre el acero y el hormigón (que pasa a ser productos de corrosión-hormigón) $(12,13)$, por la pérdida de altura de corruga y por el agrietamiento del hormigón. Todo ello supone una drástica disminución del anclaje de las barras de acero $(14,15)$. Cuando la corrosión se produce en la zona traccionada de centro de vano de una viga, las consecuencias se manifiestan fundamentalmente a nivel de estados límites de servicio, con un aumento de la fisuración y de los desplazamientos de la viga (16), si la corrosión no se detiene, la viga funcionaría en el límite como si se tratase de un arco atirantado, viéndose afectada también su resistencia. Cuando la corrosión se produce en la zona de anclaje de la armadura, las consecuencias son más graves, pudiéndose manifestar un fallo de naturaleza frágil en la estructura (17). En este caso, la existencia de armadura transversal mejora de forma significativa la resistencia residual a anclaje de la armadura corroída $(18,19)$.

El efecto beneficioso del confinamiento sobre la resistencia residual a anclaje de barras corroídas también se ha comprobado con la realización de ensayos pull-out (20, 21). A nivel de pieza, la corrosión supone una reducción de la rigidez, ductilidad y capacidad portante de la viga (22). En muchos casos también se manifiesta un cambio en el modo de fallo de ésta, rompiendo a cortante las vigas con armadura corroída, mientras que aquellas con la armadura sin corroer fallan a flexión (23).

Las consecuencias de la corrosión sobre la armadura se manifiestan con la pérdida de capacidad portante de las deteriorates and reinforcement can suffer corrosion processes.

Reinforcement corrosion is the main deteriorating factor of RCS when there is enough moisture and the passive layer has already been destroyed (1-3). The consequence is the notable reduction of the useful life of the RCS, leading to values extremely under those initially stated in the project $(4,5)$. Once the process has started, the restoration of RCS using effective methods is extremely costly $(6,7)$. However, the preventive process, when at the design and construction phases, has proved to be less expensive (8).

Corrosion effects on RCS are present in three ways: on concrete, on steel and on reinforced concrete.

Corrosion products occupy more space than the base material. Tensile stresses produced on the concrete covering due to the pressure generated by the oxides, produce concrete cracks and spallings. Small corrosion penetrations, of approximately $100 \mu \mathrm{m}$, are capable of producing fissures in the covering (9-11). The reinforcement corrosion affects its bonding performance due to the interphase variation between steel and concrete becoming concrete corrosion products $(12,13)$ because of the loss of bars height and of the concrete cracking. All this produces a strong reduction of the steel bars anchoring $(14,15)$. When the corrosion is produced at the centre of a beam span, the consequences are shown especially at service limit state levels, with an increase in cracks and beam displacement (16) if corrosion does not stop. The beam works then at the limit, like a bow string arch, and the strength is also affected. When corrosion appears at the anchoring area of the reinforcement, the consequences are more severe and it might lead to a fragile failure in the structure (17). In this case, the existence of a transversal reinforcement significantly improves the residual strength to the corroded reinforcement anchoring $(18,19)$.

The beneficial effect of confinement on the residual strength to anchoring of the corroded rods has also been observed with the pull-out tests performed $(20,21)$. At piece level, corrosion implies a reduction in the stiffness, ductility and bearing capacity of the beam (22). In many cases, a change in the type of failure of the beam also occurs; shear fracture is produced at the beams with corroded reinforcement, whereas in beams without corroded reinforcement failure appears under bending stresses (23).

Consequences of corrosion on the reinforcement can be seen in the loss of bearing capacity of the bars, due 
barras, debido principalmente a la disminución de la sección, y con la variación de su comportamiento tensióndeformación. Los ensayos realizados sobre barras corroídas muestran los cambios experimentados en el diagrama tensión deformación del acero, manifestándose una disminución sistemática de la deformación bajo carga máxima con el grado de corrosión, hasta valores que en muchos casos quedan por debajo de los mínimos exigidos por las normas y reglamentos en vigor (24-26). En estos casos, la utilización del concepto de acero equivalente como criterio de ductilidad, basado en la consideración conjunta de la deformación bajo carga máxima y el cociente entre la tensión máxima y el límite elástico, puede resultar muy ventajoso (27-29). Los criterios aplicados para la obtención del acero equivalente han seguido dos líneas conceptualmente distintas. Para algunos investigadores $(30,31)$ el criterio de acero equivalente se basa en la capacidad de giro plástico de una viga de hormigón armado, de modo que dos aceros son equivalentes si y solo si permiten la misma capacidad de giro. Otros autores han utilizado como base del criterio de acero equivalente aspectos relacionados con el diagrama tensión-deformación de una barra de acero ensayada a tracción En esta línea de trabajo, según Creazza (32), dos aceros son equivalentes cuando las áreas encerradas por la curva del diagrama tensión-deformación, la horizontal trazada por el límite elástico y la vertical trazada por el punto de tensión máxima son iguales. En esta misma línea, Ortega (33) ha definido el índice de ductilidad como el cociente entre la tenacidad y la energía elástica, de modo que dos aceros son equivalentes si presentan el mismo valor de índice de ductilidad.

Las armaduras de alta ductilidad fabricadas en España se realizan con el procedimiento Tempcore que consiste en un temple severo de la parte superficial de la barra cuando sale del tren de laminación y un posterior revenido de esta capa provocado por el calor residual que conserva el núcleo. Como consecuencia de este procedimiento de fabricación, se forman tres capas de distinta composición metalográfica en función de las distintas velocidades de enfriamiento del metal base. La corona exterior está formada por martensita, de elevada dureza y resistencia mecánica. El núcleo es de naturaleza mayoritariamente ferrítica, de elevada ductilidad. En la zona de transición entre la corona y el núcleo existe una interfase con propiedades intermedias formada por una mezcla de bainita y ferrita poligonal (34).

Bairan et al (35) han mecanizado barras de acero de alta ductilidad eliminando la capa exterior martensítica y la zona de transición. Posteriormente han sometido las barras a ensayos de tracción. La comparación entre los comportamientos tensión-deformación de barras en las que no se ha eliminado la capa exterior y de barras mecanizadas permite obtener muy aproximadamente el comportamiento de la corona exterior. Los resultados muestran que la sección mainly to the reduction of the section, and to the variation of the stress-strain behaviour. Tests performed on the corroded bars show the changes experimented in the steel stress-strain diagram: a systematic decrease of the deformation when subject to maximum load can be observed as corrosion degree progresses; this leads up to values clearly lower than the minimum ones required by the en force standards (24-26). In these cases, the use of an equivalent steel concept as a ductility criteria, can be highly advantageous, based on the joint consideration of the deformation under maximum load and the ratio between maximum stress and elastic limit (27-29). Criteria applied to obtain equivalent steel have followed two conceptually different ways. For some researchers $(30,31)$, the criteria of equivalent steel is based on the plastic twisting capacity of a reinforced concrete beam. Other authors have used as steel equivalent criteria base aspects related to the tensionstrain diagram of a steel bar tested to tensile stress. In this research line, according to Creazza (32), two steels are equivalent when the areas enclosed by the curve of the stress-strain diagram, the horizontal line drawn by the elastic limit and the vertical one drawn by the point of maximum tension are equal. Similarly, Ortega (33) has defined the ductility index as the quotient between toughness and elastic energy, in such a way that two steel are equivalent if they present the same ductility index value.

High ductility reinforcements produced in Spain are manufactures following the Tempcore procedure consisting in a severe toughness of the bar superficial side when it leaves the rolling machine, and a later tempering of this layer causing the residual heat which the core maintains. As a consequence of this manufacturing process, three layers of different metallographic composition are formed in relation to the different cooling speeds of the base metal. The external crown is formed by martensite, of high hardness and mechanical strength. The core is mainly of ferrite nature and high ductility. In the transition area between the crown and the core, there is an interpose with intermediate properties formed by a mixture of bainite and polygonal ferrite (34).

Bairan et al (35) have mechanized high ductility steel bars eliminating the external martensite layer and the transition zone. The comparison between the bar tension-strain performance, in which the external layer has not been eliminated, and that of the mechanized bars shows a very similar performance of the external crown. The results show that the core section has a strain capacity, measured in terms of $\varepsilon_{\max }$ and $\varepsilon_{u, 5}$, and 
del núcleo posee una capacidad de deformación, medida en términos de $\varepsilon_{\max } y \varepsilon_{u, 5}$, y un valor $f_{s /} f_{y}$ muy superior a los de la corona exterior. En concreto, el valor $f_{s /} f_{y}$ obtenido para el núcleo es de aproximadamente 1,30, mientras que para la corona exterior el cociente se ve reducido a 1,15.

En este trabajo se muestran los resultados obtenidos sobre barras de acero para armar con distintos niveles de corrosión ensayadas a tracción. Los objetivos principales de este trabajo han sido identificar los mecanismos que provocan la variación de las propiedades mecánicas de las barras corroídas y obtener modelos que permitan predecir las propiedades mecánicas del acero en función de su grado de corrosión.

\section{TRABAJO EXPERIMENTAL REALIZADO}

\subsection{Corrosión de armaduras}

Para determinar la evolución de las características mecánicas del acero con el proceso de corrosión, se han fabricado 12 losas de hormigón de dimensiones 46 × 60 × $10 \mathrm{~cm}$ en las que se han embebido 96 barras de acero B500SD de diámetros 16 y $20 \mathrm{~mm}$ (Figura 1). Este tipo de acero posee características especiales de ductilidad y está indicado para ser usado en zona sísmica, además es el que se emplea de forma mayoritaria en España en obras de edificación. En la Tabla 1 se indican las características mecánicas mínimas que debe cumplir, según la instrucción EHE-08 (36). a $f_{s /} f_{y}$ value highly greater than those of the external crown. More specifically, $f_{s} / f_{y}$ value, obtained for the core is approximately 1.30 whereas for the external crown the quotient is reduced to 1.15 .

This research work shows the results obtained with steel rods at different corrosion levels tested for tensile strength. The main aim of this study has been to identity the mechanisms causing the variations of mechanical properties of the corroded bars and to obtain models which allow us to predict steel mechanical properties regarding its corrosion degree.

\section{EXPERIMENTAL PROCEDURE}

\subsection{Reinforcement corrosion}

In order to determine steel mechanical characteristics within the process of corrosion, 12 concrete slabs have been manufactured with dimensions $46 \times 60 \times 10 \mathrm{~cm}$. In these slabs, 96 bars of B500SD steel, and diameter 16 and $20 \mathrm{~mm}$ (Figure 1) have been embedded. This type of steel presents special ductility characteristics and is appropriate to be used in seismic areas. In addition, it is the most commonly used steel in Spain in construction works. Table 1 shows the minimum mechanical characteristics required, as stated in the EHE-08 code (36).

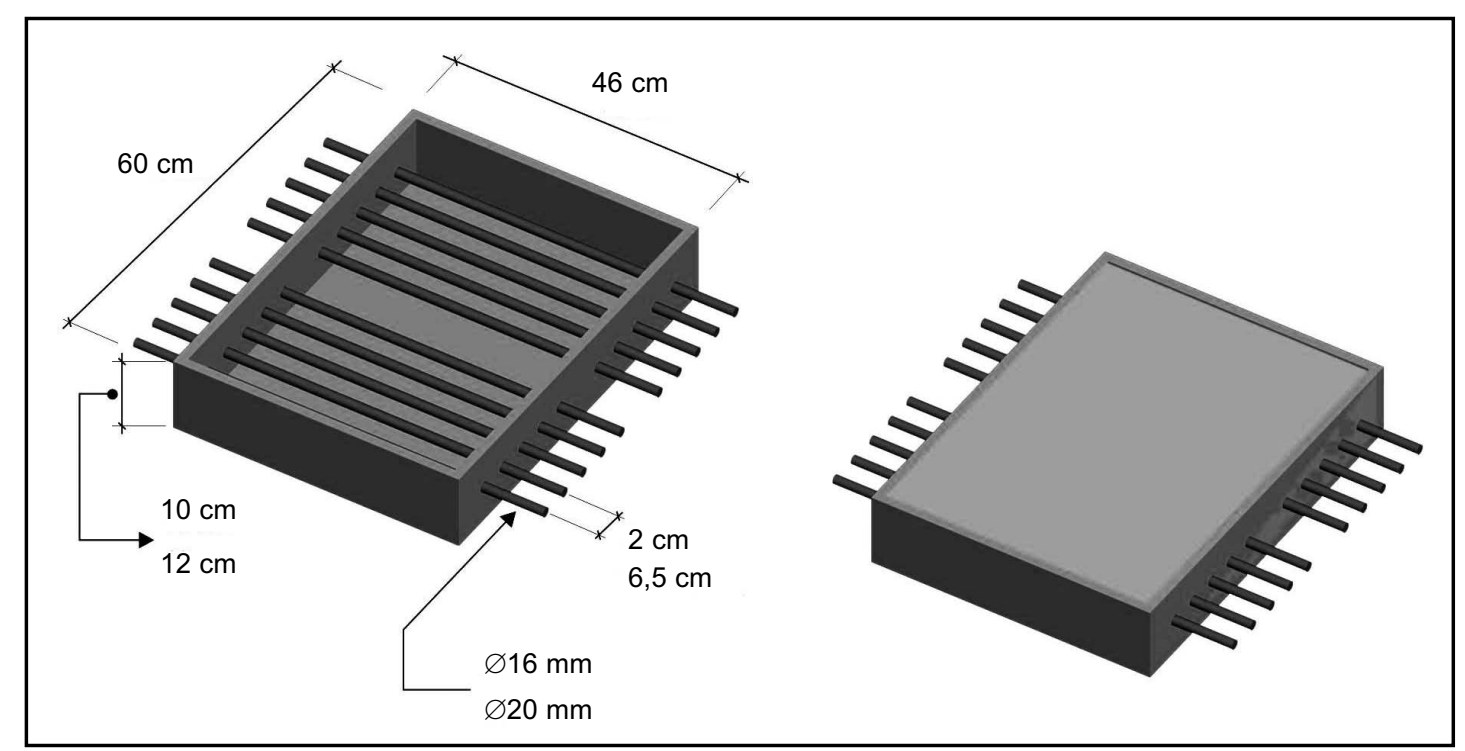

Figura 1. Detalle de una de las losas de hormigón.

Figure 1. Detail of one of the concrete slabs.

Tabla 1 / Table 1

Requerimientos mecánicos para el acero B500SD según EHE-08. Minimum mechanical requirements for B500SD steel as stated in the EHE-08 code.

\begin{tabular}{|c|c|c|c|c|}
\hline $\mathbf{f}_{\mathbf{y}}\left(\mathbf{N} / \mathbf{m m}^{2}\right)$ & $\mathbf{f}_{\mathbf{s}}\left(\mathbf{N} / \mathbf{m m}^{2}\right)$ & $\varepsilon_{\mathrm{u}, 5}(\%)$ & $\varepsilon_{\max }(\%)$ & $\mathbf{f}_{\mathbf{s}} / \mathbf{f}_{\mathrm{y}}$ \\
\hline 500 & 575 & 16 & 7.5 & $1.15-1.35$ \\
\hline
\end{tabular}


Donde $\mathrm{f}_{\mathrm{y}}=$ tensión en el límite elástico, $\mathrm{f}_{\mathrm{s}}=$ tensión máxima, $\varepsilon_{\mathrm{u}, 5}=$ deformación en rotura medida sobre 5 diámetros que incorporan la zona de estricción, $\varepsilon_{\max }=$ deformación correspondiente a la tensión máxima.

En la fabricación de las doce losas se ha empleado hormigón al que se le ha añadido ión cloruro, en forma de cloruro cálcico, con una concentración de un $2 \%$ en peso de cemento. Después del hormigonado y desencofrado, los elementos se han curado en cámara húmeda a una temperatura de $25^{\circ} \mathrm{C}$ y una humedad del $99 \%$ durante 28 días.

Para evitar el ataque preferente que pudiera provocar la corrosión localizada en la interfase hormigón-aire, la parte de las armaduras situada en esa zona de heterogeneidad fue cubierta con cinta aislante, de forma que la cinta rodease la armadura en una longitud aproximada de $2 \mathrm{~cm}$ dentro y fuera del hormigón.

Se han cortocircuitado externamente las barras de acero y se ha forzado la corrosión mediante la aplicación de una corriente anódica constante entre la armadura y una plancha de plomo colocada sobre la superficie de las losas. El reparto homogéneo de la corriente se ha conseguido interponiendo entre la superficie de las losas y la lámina de plomo una bayeta empapada con agua que se ha ido humedeciendo a medida que se ha ido secando (Figura 2).

Durante el proceso, se ha registrado periódicamente la corriente que pasa por cada una de las barras utilizando un multímetro digital, realizando medidas en intervalos de dos o tres días y corrigiendo cualquier caída de corriente mediante la variación del potencial eléctrico de la fuente de alimentación. La densidad media de corriente en cada una de las barras ha sido aproximadamente $10 \mu \mathrm{A} / \mathrm{cm}^{2}$. Esta densidad de corrosión se ha obtenido en estructuras reales expuestas a ambientes con cloruros cuando existe suficiente humedad (37).

Las barras se han ido desconectando de la fuente de corriente en distintos momentos para conseguir niveles variables de ataque por corrosión de las armaduras.
Where $f_{y}=$ yield strength, $f_{s}=$ ultimate strength, $\varepsilon_{u, 5}=$ fracture strain measured at 5 diameters incorporating the necking area, and $\varepsilon_{\max }=$ ultimate strain.

During the 12 slab manufacture, chloride ion has been added to the concrete used, as calcium chloride, in a 2\% concentration by cement weight. After placing the concrete and removing the formwork, the elements have been cured in a moisture chamber at $25^{\circ} \mathrm{C}$ temperature and $99 \%$ humidity for 28 days.

To avoid the main failure which corrosion placed at the concrete-air interphase area produces, the reinforcement placed in this heterogeneous area were covered with insulating tape, surrounding the reinforcement bars $2 \mathrm{~cm}$ inside and outside the concrete.

Steel bars were then externally short-circuited and corrosion forced by applying a constant anodic current between the reinforcement and a lead plank placed on the surface of the slabs. Homogeneous distribution of the current has been achieved inserting between the slab surface and the lead sheet a wet cloth, which has been moisturized as it dried (Figure 2).

During the process, the current passing through each of the bars has been checked using a digital multimeter and registering the data at two or three day's interval. In this way, any voltage dip could be corrected by the electric potential variation of the power supply. The average corrosion density on each of the bars has been approximately of $10 \mu \mathrm{A} / \mathrm{cm}^{2}$. This corrosion density has been obtained in real structures exposed to chloride environments when there is enough humidity (37).

Bars were disconnected from the power supply at different moments to achieve different levels of reinforcement corrosion attacks.

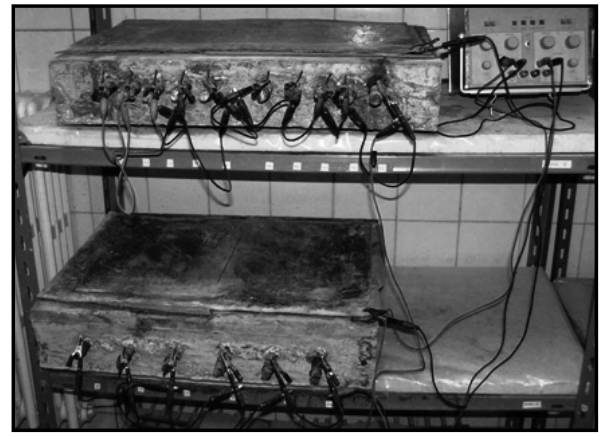

Figura 2. Conexión de las losas durante el ensayo de corrosión acelerada Figure 2. Slab assembly during an accelerated corrosion test. 


\subsection{Estudio experimental de las características mecánicas de las armaduras}

Una vez finalizado el proceso de corrosión acelerada de las armaduras en las losas de hormigón y después de la extracción de las barras y de la eliminación del óxido formado por decapado químico, las barras se han ensayado a tracción, obteniendo los datos necesarios para construir sus diagramas tensión-deformación.

Los ensayos de tracción se han realizado, siguiendo la norma UNE-EN 10002-1 (38), en una prensa de accionamiento hidráulico y servocontrolada, con mordazas hidráulicas de presión regulable, modelo MIB-40-MODAM, con capacidad de carga de $61040 \mathrm{~N}$ actualizada mediante el programa informático WINTEST32 como sistema de adquisición de datos. Los ensayos se han realizado con control por carga en el tramo elástico y control por deformación una vez superado el límite elástico. Las medidas de deformación se han obtenido con un extensómetro de base $50 \mathrm{~mm}$, JB-MFA-2.

Las armaduras se han identificado mediante un código del tipo $B-X X-Y Y$ donde $X X$ es el número de probeta e YY es el diámetro de la barra en $\mathrm{mm}$. Las barras que no han sufrido un proceso de corrosión y sirven de referencia se han identificado como B-RE-YY. Antes del ensayo se han realizado sobre las barras marcas equidistantes con rotulador indeleble, con el objeto de determinar, una vez producida la rotura, la deformación bajo carga máxima y la deformación última medida en base de 5 diámetros.

\subsection{Estudio metalográfico}

Se han realizado estudios metalográficos del acero para comprobar la influencia de la corrosión en su microestructura, determinar el avance de la misma desde la periferia, su efecto sobre las distintas fases metalográficas y relacionarla con las propiedades mecánicas obtenidas en los ensayos de tracción. También se han realizado micrografías de la superficie de fractura cortando probetas en los extremos de rotura después del ensayo de tracción.

\subsection{Microdureza Vickers}

Para complementar el estudio metalográfico, se han realizado medidas de microdureza Vickers, utilizando una carga de $1000 \mathrm{~N}$, con un equipo digital Microhardness Tester HVS-1000.

Las determinaciones se han realizado sobre las armaduras sin corroer y sobre las armaduras corroídas. Se han registrado los valores de microdureza a intervalos de medio milímetro sobre la sección transversal de la barra, siguiendo su diámetro.

\subsection{Experimental survey of the reinforcement mechanical properties}

Once the accelerated corrosion process of the reinforced concrete slabs has finished and after removing the bars and eliminating the corrosion formed by the chemical pickling, the bars were tested to tensile strength, obtaining the necessary data to construct stress-strain curves.

Tensile strength tests have been performed following UNE-EN 10002-1 (38) standards in a hydraulic servo controlled press machine, MIB-40-MOD-AM, with adjustable pressure hydraulic clamps and a load capacity of $61040 \mathrm{~N}$. This equipment has been upgraded with a WINTEST32 software computer program to register data. Tests have been carried out with load control on the elastic area and strain control once the yield limit has been surpassed. The strain measurements have been obtained with a JB-MFA-2 strain gauge of base $50 \mathrm{~mm}$.

The reinforcements have been identified by a $B-X X-Y Y$ code, where $X X$ refers to a sample number and $Y Y$ is the bar diameter in $\mathrm{mm}$. Bars which have not suffered a corrosion process, and serve as reference, have been identified as B-RE-YY. Before the test, equidistant marks have been placed on the bars with a permanent pen to determine the strain under the maximum load and the ultimate strain measured in a 5 diameter base, once the fracture has occurred.

\subsection{Metallographic study}

Steel metallographic surveys have been performed to prove the influence of corrosion in its microstructure, to determine the progress of corrosion from the periphery, to establish its effect on the different metallographic phases and to relate it to the mechanical properties obtained in the tensile strength tests. In addition, fracture surface micrographies have been performed cutting the specimens at the fracture edges after the tensile strength test.

\subsection{Vickers microhardness}

To complete the metallographic survey, Vickers micro hardness measurements, with a load of $1000 \mathrm{~N}$, have been performed using a HVS-1000 digital micro hardness Tester.

Data has been registered from the corroded reinforcement bars and from the non-corroded one. Micro hardness values have been registered at half a millimetre intervals on the transversal section of the bar, following its diameter. 


\section{RESULTADOS}

\subsection{Características mecánicas de las armaduras corroídas}

Los resultados de los ensayos de tracción se indican en las Tablas 2 (barras de diámetro 16) y 3 (barras de diámetro 20) donde se aportan los datos correspondientes a las propiedades mecánicas de las barras ensayadas:

\section{RESULTS}

\subsection{Mechanical properties of the corroded reinforcement}

Results of the tensile strength tests are shown on Table 2 (16 diameter bars) and 3 (20 diameter bars) where data corresponding to the mechanical properties of the tested bars: maximum strength $\left(f_{s}\right)$, elastic limit strength

Tabla 2 / Table 2

Características mecánicas de las armaduras de diámetro $16 \mathrm{~mm}$ después del proceso de corrosión. Mechanical characteristics of diameter 16 bars after the process of corrosion*.

\begin{tabular}{|c|c|c|c|c|c|c|}
\hline Bar & Corr (\%) & $\mathrm{f}_{\mathrm{s}}\left(\mathrm{N} / \mathrm{mm}^{2}\right)$ & $f_{y}\left(N / m m^{2}\right)$ & $\overline{f_{s} / / f_{y}}$ & $\varepsilon_{\text {máx }}$ & $\varepsilon_{\mathrm{u}, 5}$ \\
\hline Rsc-16 & 0.0 & 649.10 & 540.92 & 1.20 & 10.7 & 21.2 \\
\hline B-74-16 & 4.0 & 632.38 & 517.48 & 1.22 & 8.5 & 17.5 \\
\hline B-96-16 & 5.0 & 636.94 & 533.83 & 1.19 & 10.3 & 18.7 \\
\hline B-69-16 & 5.1 & 652.92 & 531.03 & 1.23 & 9.9 & 20.0 \\
\hline B-6-16 & 5.9 & 631.30 & 522.49 & 1.21 & 9.0 & 22.5 \\
\hline B-71-16 & 6.6 & 672.61 & 562.10 & 1.20 & 8.8 & 17.5 \\
\hline B-26-16 & 6.8 & 616.56 & 458.25 & 1.34 & 10.1 & 18.7 \\
\hline B-5-16 & 7.1 & 640.84 & 528.21 & 1.21 & 8.5 & 21.2 \\
\hline B-7-16 & 7.1 & 644.30 & 522.74 & 1.23 & 8.9 & 18.7 \\
\hline B-68-16* & 7.4 & 645.23 & 525.66 & 1.23 & 9.6 & $15.0^{*}$ \\
\hline B-72-16* & 7.5 & 634.05 & 505.82 & 1.25 & 7.9 & $15.0^{*}$ \\
\hline B-66-16* & 7.9 & 633.08 & 530.27 & 1.19 & 7.5 & $13.7^{*}$ \\
\hline B-36-16 & 7.9 & 665.58 & 552.80 & 1.20 & 9.1 & $14.2^{*}$ \\
\hline B-70-16* & 8.0 & 642.55 & 543.22 & 1.18 & 7.4* & 16.2 \\
\hline B-23-16 & 8.1 & 616.13 & 498.06 & 1.24 & 8.4 & 17.5 \\
\hline B-25-16* & 8.1 & 610.62 & 469.30 & 1.30 & 7.8 & $13.7 *$ \\
\hline B-94-16* & 8.5 & 653.04 & 550.14 & 1.19 & 8.9 & $15.0^{*}$ \\
\hline B-24-16 & 8.8 & 602.29 & 470.87 & 1.30 & 7.6 & 18.7 \\
\hline B-8-16 & 9.0 & 635.85 & 518.06 & 1.23 & 8.2 & 20.0 \\
\hline B-47-16 & 9.1 & 647.80 & 528.90 & 1.22 & 10.3 & 16.2 \\
\hline B-95-16* & 9.2 & 658.14 & 554.11 & 1.19 & 6.4* & $13.7^{*}$ \\
\hline B-3-16* & 9.7 & 619.20 & 537.09 & 1.15 & $5.0^{*}$ & 17.5 \\
\hline B-38-16* & 10.1 & 626.51 & 523.57 & 1.20 & 9.1 & $14.5^{*}$ \\
\hline B-33-16 & 10.3 & 582.36 & 474.75 & 1.23 & 8.9 & 17.1 \\
\hline B-4-16* & 11.4 & 637.48 & 518.06 & 1.23 & $7.2^{*}$ & 18.7 \\
\hline B-65-16* & 11.4 & 578.87 & 458.97 & 1.26 & $7.0^{*}$ & $15.0^{*}$ \\
\hline B-49-16 & 11.8 & 616.48 & 469.32 & 1.31 & 8.4 & 17.5 \\
\hline B-52-16* & 11.9 & 591.00 & 495.85 & 1.19 & $6.2^{*}$ & $12.5^{*}$ \\
\hline B-51-16* & 12.3 & 617.62 & 517.40 & 1.19 & $6.8^{*}$ & $13.7^{*}$ \\
\hline B-34-16* & 12.3 & 593.73 & 491.95 & 1.21 & 7.8 & $12.7^{*}$ \\
\hline B-53-16* & 12.4 & 609.23 & 512.10 & 1.19 & $6.8^{*}$ & 16.2 \\
\hline B-50-16* & 13.0 & 594.38 & 504.37 & 1.18 & $5.6^{*}$ & $13.7 *$ \\
\hline B-48-16* & 13.3 & 621.47 & 506.73 & 1.23 & 7.9 & $13.7^{*}$ \\
\hline B-37-16 & 13.6 & 633.20 & 527.68 & 1.20 & 7.6 & 16.2 \\
\hline B-46-16* & 13.7 & 620.42 & 514.14 & 1.21 & $6.9^{*}$ & $13.7^{*}$ \\
\hline B-9-16* & 14.0 & 622.22 & 506.90 & 1.23 & 7.0* & $15.2^{*}$ \\
\hline B-45-16* & 15.1 & 574.25 & 519.30 & $1.11^{*}$ & $4.1^{*}$ & $11.2^{*}$ \\
\hline B-35-16* & 15.2 & 622.61 & 521.18 & 1.19 & 7.9 & $15.5^{*}$ \\
\hline B-1-16* & 15.3 & 643.55 & 525.73 & 1.22 & $7.4^{*}$ & 15.0* \\
\hline
\end{tabular}

En las tablas, el asterisco se refiere a las barras en las cuales los valores de alguno de los parámetros que indican la ductilidad han resultado por debajo de los límites establecidos por la EHE-08 para los aceros con características especiales de ductilidad. / In all tables the asterisk (*) refers to the bars in which the values of one of the mechanical ductility indicators resulted lower than the limits established by the EHE-08 code for steels with special ductility characteristics. 
resistencia máxima $\left(\mathrm{f}_{\mathrm{s}}\right)$, resistencia en el límite elástico $\left(f_{y}\right)$, relación entre $f_{s} / f_{y}$, deformación bajo carga máxima $\left(\varepsilon_{\max }\right)$ y deformación última medida sobre la base de cinco diámetros $\left(\varepsilon_{\mathrm{u}, 5}\right)$. El nivel de corrosión alcanzado en cada una de ellas se expresa mediante la variable $\mathrm{Q}_{\text {corr }}$ que representa la pérdida de masa (o de sección) de la barra debido al proceso de corrosión. Las determinaciones de las características mecánicas se han hecho en relación a la sección equivalente, obtenida como la sección media de las barras después del proceso de corrosión. Su valor se ha calculado gravimétricamente, pesando las barras después de eliminar los productos de corrosión, y suponiendo que la pérdida de acero se produce de manera uniforme sobre la longitud de la barra corroída.

La Tabla 2 muestra que los valores de $f_{s}$ para las barras de diámetro 16 y de $\mathrm{f}_{\mathrm{y}}$ van desde el valor 574,25 a $672,61 \mathrm{~N} / \mathrm{mm}^{2}$ y 458,25 a $562,10 \mathrm{~N} / \mathrm{mm}^{2}$, respectivamente. La relación entre $f_{s} / f_{y}$ oscila entre 1,11 y 1,34 y el valor de $\varepsilon_{\max }$ desde 4,1 a $10,7 \%$. Los valores obtenidos de $\varepsilon_{\mathrm{u}}, 5$, van desde $11,2 \%$ a $22,5 \%$.

La Tabla 3 muestra cómo los valores de resistencias para las barras de diámetro $20 \mathrm{~mm}$ oscilan entre 594,96 y $677,87 \mathrm{~N} / \mathrm{mm}^{2}$ para la resistencia máxima, y 459,65 a $592,36 \mathrm{~N} / \mathrm{mm}^{2}$ para el límite elástico. El valor de la deformación máxima está comprendido entre 5,1 y $12,8 \%$ y la deformación última bajo base de cinco diámetros entre 11 y $27 \%$.

En ambas tablas se han marcado con asterisco (*) las barras en las que los valores de alguno de los parámetros mecánicos indicadores de la ductilidad han resultado inferiores a los límites exigidos por la Instrucción EHE-08 para los aceros con características especiales de ductilidad. También se han marcado del mismo modo los valores que no superan la norma.

Puede comprobarse, en ambas tablas, cómo valores de penetración media de corrosión de hasta el 7,4\% o 6,6\%, en función del diámetro de la barra, no implican reducciones en las propiedades mecánicas del acero que supongan el no cumplimiento de la Instrucción EHE. A partir de los valores anteriores y hasta pérdidas del $11,4 \%$ ó $8,5 \%$, aproximadamente la mitad de las barras no superan las especificaciones de ductilidad de la Instrucción EHE. Cuando la penetración media de corrosión excede de los valores indicados anteriormente, prácticamente todas las barras son incapaces de superar las especificaciones de ductilidad.

En la Figura 3 se muestran los diagramas tensión-deformación representativos del comportamiento de las 96 barras ensayadas. El diagrama D-1 corresponde al de barras patrón por las que no ha pasado corriente y no han sufrido un proceso de corrosión. El diagrama D-2 $\left(f_{y}\right), f_{s} / f_{y}$ ratio, strain under maximum load $\left(\varepsilon_{\text {max }}\right)$ and ultimate deformation measured on a five diameter base $\left(\varepsilon_{u, 5}\right)$. The level of corrosion reached in each one of them is registered by the $Q_{c o r r}$ variable representing the bar mass loss (or section loss) due to the corrosion process. Mechanical characteristics have been determined in relation to the equivalent section, obtained as the bar average section after the corrosion process. Its value has been gravimetrically calculated, weighing the bars after having eliminated the corrosion products and supposing the steel loss is produced in a uniform way over the length of the corroded bar.

Table 2 shows the ultimate strength values $\left(f_{s}\right)$ for the bars with diameter 16 , and the yield strength $\left(f_{y}\right)$ values, which span from 574.25 to $672.61 \mathrm{~N} / \mathrm{mm}^{2}$ and 458.25 to 562.10 $\mathrm{N} / \mathrm{mm}^{2}$ respectively. The $f_{s} / f_{y}$ ratio moves between 1.11 and 1.34 and the value of the ultimate stress strain $\left(\varepsilon_{\text {max }}\right)$ varies from 4.1 to $10.7 \%$. Values obtained for the lengthening on five diameters $\left(\varepsilon_{u, 5}\right)$, vary from $11.2 \%$ to $22.5 \%$.

Table 3 shows strength values for bars $20 \mathrm{~mm}$ in diameter fluctuating between 594.96 and $677.87 \mathrm{~N} / \mathrm{mm}^{2}$ for ultimate strength and from 459.65 to $592.36 \mathrm{~N} / \mathrm{mm}^{2}$ for ultimate yield strength. The maximum strain value is among 5.1 and $12.8 \%$ and the ultimate strain under a 5 diameter base is in between 11 and $27 \%$.

In both tables the asterisk $\left(^{*}\right)$ refers to the bars in which the values of one of the mechanical ductility indicators resulted lower than the limits established by the EHE-08 code for steels with special ductility characteristics. In addition, values, which do not comply with the code, have also been marked in the same way.

As can be seen in both tables, average corrosion penetration values of up to $7.4 \%$ or $6.6 \%$, regarding the bar diameter, do not imply reductions in the steel mechanical properties and therefore comply with the EHE code. From the latter values and up to $11.4 \%$ or $8.5 \%$ losses, approximately half of the bars do not fulfil the ductility specifications of the EHE code. When the average corrosion penetration exceeds the indicated values, practically none of the bars reaches the specifications established in the code.

Figure 3 presents the stress-strain diagrams showing the significant behaviour of the 96 bars tested. Diagram D-1 corresponds to the standard bar, which has not been subject to a current and has not corroded. Diagram D-2 represents the bars after the corrosion process, having 
Tabla 3 / Table 3

Características mecánicas de las armaduras de $20 \mathrm{~mm}$ de diámetro después del proceso de corrosión.

Mechanical characteristics of bars 20 in diameter after corrosion process*.

\begin{tabular}{|c|c|c|c|c|c|c|}
\hline Bar & Corr (\%) & $f_{s}\left(N / m^{2}\right)$ & $f_{y}\left(N / m^{2}\right)$ & $\mathrm{f}_{\mathrm{s}} / / \mathrm{f}_{\mathrm{y}}$ & $\varepsilon_{\text {máx }}$ & $\overline{\varepsilon_{u, 5}}$ \\
\hline Rsc-20 & 0.0 & 666.12 & 550.24 & 1.21 & 12.8 & 27 \\
\hline B-29-20 & 2.1 & 627.95 & 498.80 & 1.26 & 8.1 & 20 \\
\hline B-27-20 & 2.3 & 672.30 & 513.09 & 1.31 & 10.3 & 19 \\
\hline B-31-20 & 2.3 & 624.65 & 503.30 & 1.24 & 8.1 & 21 \\
\hline B-18-20 & 2.9 & 666.84 & 556.38 & 1.20 & 10.1 & 21 \\
\hline B-13-20 & 3.2 & 661.06 & 564.24 & 1.17 & 8.9 & 23 \\
\hline B-12-20 & 3.2 & 661.86 & 550.24 & 1.20 & 9.8 & 22 \\
\hline B-28-20 & 3.4 & 663.79 & 555.50 & 1.19 & 11.3 & 20 \\
\hline B-20-20 & 3.9 & 668.60 & 514.71 & 1.30 & 12.1 & 18 \\
\hline B-19-20 & 4.0 & 677.87 & 514.77 & 1.32 & 12.5 & 21 \\
\hline B-14-20 & 4.8 & 652.77 & 560.67 & 1.16 & 8.6 & 19 \\
\hline B-32-20 & 5.1 & 654.00 & 490.00 & 1.33 & 10.3 & 16 \\
\hline B-16-20 & 5.2 & 671.82 & 586.13 & 1.15 & 9.2 & 22 \\
\hline B-11-20 & 5.5 & 652.17 & 505.16 & 1.29 & 10.3 & 20 \\
\hline B-77-20 & 5.8 & 649.72 & 542.07 & 1.20 & 9.1 & 17 \\
\hline B-88-20 & 6.1 & 621.47 & 505.58 & 1.30 & 9.3 & 17 \\
\hline B-30-20 & 6.4 & 660.73 & 513.10 & 1.29 & 10.7 & 17 \\
\hline B-76-20* & 6.6 & 637.46 & 526.23 & 1.21 & 8.3 & $12^{*}$ \\
\hline B-59-20 & 7.1 & 603.80 & 487.35 & 1.24 & 9.4 & 18 \\
\hline B-83-20* & 7.3 & 657.81 & 561.92 & 1.17 & 8.9 & $12^{*}$ \\
\hline B-17-20 & 7.3 & 627.95 & 555.02 & 1.19 & 8.7 & 17 \\
\hline B-60-20* & 7.5 & 613.94 & 497.16 & 1.23 & $7.0^{*}$ & $15^{*}$ \\
\hline B-58-20* & 7.7 & 642.97 & 535.75 & 1.20 & 9.3 & 13* \\
\hline B-56-20 & 7.9 & 652.73 & 545.75 & 1.20 & 10.4 & 19 \\
\hline B-81-20 & 8.0 & 643.59 & 534.57 & 1.20 & & 17 \\
\hline B-57-20 & 8.3 & 651.58 & 544.21 & 1.20 & 12.0 & 18 \\
\hline B-61-20* & 8.5 & 596.10 & 459.65 & 1.30 & 8.4 & $11^{*}$ \\
\hline B-55-20* & 8.6 & 610.57 & 503.07 & 1.21 & 8.3 & $11^{*}$ \\
\hline B-15-20* & 8.9 & 659.82 & 592.36 & 1.11 & $7.1^{*}$ & 16 \\
\hline B-63-20* & 9.2 & 610.54 & 532.67 & 1.15 & $5.1^{*}$ & $13 *$ \\
\hline B-87-20* & 9.5 & 620.93 & 505.54 & 1.23 & 8.3 & $15^{*}$ \\
\hline B-79-20* & 10.2 & 612.96 & 485.00 & 1.26 & 8.1 & 14* \\
\hline B-86-20* & 10.5 & 639.54 & 518.94 & 1.23 & 8.0 & 14* \\
\hline B-64-20* & 11.2 & 601.18 & 512.56 & 1.17 & $6.7^{*}$ & $12^{*}$ \\
\hline B-75-20* & 11.2 & 613.11 & 497.34 & 1.23 & 8.3 & 13* \\
\hline B-89-20* & 11.5 & 650.86 & 542.04 & 1.20 & 9.5 & $15^{*}$ \\
\hline B-84-20* & 12.0 & 631.33 & 487.78 & 1.29 & 9.3 & $14 *$ \\
\hline B-62-20 & 12.2 & 615.45 & 490.34 & 1.25 & 8.2 & 16 \\
\hline B-44-20* & 12.3 & 601.00 & 482.22 & 1.25 & $6.8^{*}$ & $13^{*}$ \\
\hline B-39-20* & 12.8 & 604.09 & 473.25 & 1.28 & $6.7^{*}$ & $15^{*}$ \\
\hline B-85-20* & 13.2 & 594.96 & 470.50 & 1.26 & 7.3* & $13^{*}$ \\
\hline B-80-20* & 13.5 & 654.77 & 539.00 & 1.21 & 8.3 & $14^{*}$ \\
\hline B-42-20* & 14.2 & 615.11 & 485.47 & 1.27 & $7.2^{*}$ & $12^{*}$ \\
\hline B-90-20* & 14.3 & 625.42 & 486.33 & 1.29 & 8.8 & $13^{*}$ \\
\hline B-41-20* & 14.4 & 611.84 & 490.87 & 1.25 & $6.9^{*}$ & 13* \\
\hline B-43-20* & 14.6 & 618.23 & 512.50 & 1.21 & 6.9* & 14* \\
\hline
\end{tabular}

En las tablas, el asterisco se refiere a las barras en las cuales los valores de alguno de los parámetros que indican la ductilidad han resultado por debajo de los límites establecidos por la EHE-08 para los aceros con características especiales de ductilidad. / In all tables the asterisk (*) refers to the bars in which the values of one of the mechanical ductility indicators resulted lower than the limits established by the EHE-08 code for steels with special ductility characteristics. 
representa a las barras que después del proceso de corrosión han experimentado una pérdida de sección media de hasta un $4 \%$ respecto de la inicial. Los diagramas D-3, D-4 y D-5 representan situaciones con pérdidas medias de sección en los intervalos 4\%-8\%, 8\%$12 \%$ y $12 \%-16 \%$, respectivamente.

Las barras R-16 y R-20 por las que no ha pasado corriente (diagrama D-1) muestran un comportamiento típico tensión-deformación de barras de acero laminadas en caliente para hormigón estructural. Después de alcanzado el límite elástico, se produce un periodo de cedencia hasta una deformación de aproximadamente un 4\%, después del cual sucede un fortalecimiento del material por el proceso de endurecimiento en frío. Los valores medios de deformación máxima, relación $\mathrm{f}_{\mathrm{s}} / \mathrm{f}_{\mathrm{y}}$ y alargamiento medido bajo cinco diámetros son $11,7 \%, 1,20$ y $24,1 \%$, respectivamente. Estos valores están por encima de los mínimos exigidos por la normativa para aceros de alta ductilidad.

Sin embargo, a medida que avanza el proceso de corrosión, el diagrama tensión-deformación experimenta cambios notables. El escalón de cedencia disminuye drásticamente o desaparece y las barras pasan a comportarse como si se tratase de un acero deformado en frío. Los valores correspondientes a la tensión en el límite elástico y la tensión máxima disminuyen ligeramente y los valores correspondientes a la deformación, bien sea la deformación bajo carga máxima o la deformación medida bajo cinco diámetros, disminuyen significativamente. experienced a section loss of up to $4 \%$ in relation to the initial one. Diagrams D-3, D-4 and D-5 represent situations with average losses in between $4 \%-8 \%, 8 \%$ $12 \%$ and $12 \%-16 \%$, respectively.

$R-16$ and $R-20$ bars, not subject to current (diagram $D$ 1) show the typical stress-strain behaviour of bars, made of heat rolled steel for structural concrete. Once the elastic limit has been reached, a period of deformation of approximately $4 \%$ is produced. After this period, the material strengthens by the hardening cooling process. The average maximum strain values, the $f_{s} / f_{y}$ ratio and the lengthening measured for five diameters are $11.7 \%$, 1.20 and $24.1 \%$, respectively. These values are clearly over the minimum ones established for the high ductility steel by the codes.

However, as the corrosion process proceeds, the stressstrain diagram reveals significant changes. The yield range diminishes drastically, or disappears and the bars perform in a similar way to that of cold strain steel. The values corresponding to the ultimate yield strength and the ultimate stress slightly diminish; and the strain values, whether it be strain under ultimate stress or strain measured for the five diameters diminishes significantly.

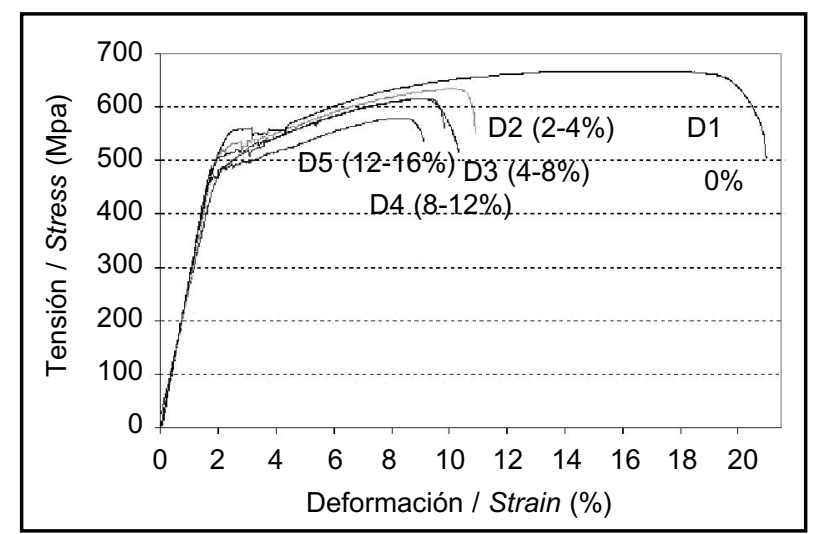

Figura 3. Resumen de los resultados del ensayo de tracción de las 96 armaduras.

Figure 3. Summary of tensile test results for the 96 bars.

\subsection{Estudio metalográfico}

En la Figura 4 se muestra la micrografía de la zona de fractura de una barra de diámetro $16 \mathrm{~mm}$ que no ha sufrido un proceso de corrosión. La Figura 5 corresponde a la micrografía en la zona de fractura de una barra del mismo diámetro que ha experimentado un proceso

\subsection{Metallographic survey}

Figure 4 shows the micrography of the fractured area of a $16 \mathrm{~mm}$ diameter bar, which has not undergone a corrosion process. Figure 5 corresponds to the micrography area of a bar equal in diameter but which has undergone a corrosion process with a significant 


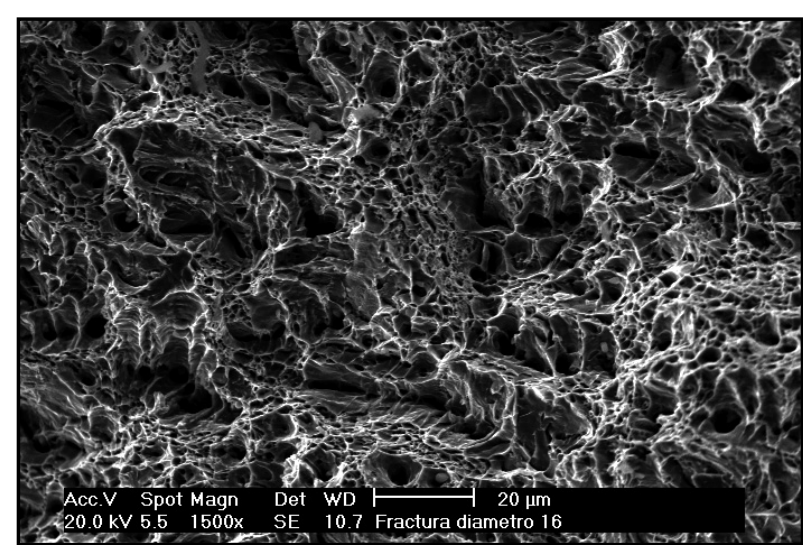

Figura 4. Micrografía de la fractura de la armadura de $16 \mathrm{~mm}$ que no ha sufrido corrosión.

Figure 4. Micrography of the fracture area of a $16 \mathrm{~mm}$ diameter bar, which has not undergone a corrosion process.

de corrosión con una pérdida significativa de sección media. Las dos micrografías ofrecen un mismo aspecto de la forma de fractura: coalescencia de microhuecos, lo que evidencia una rotura de tipo dúctil.

\subsection{Microdureza Vickers}

Las Figuras 6 y 8 muestran los resultados obtenidos de microdureza Vickers para la sección transversal de la barra de 16 y $20 \mathrm{~mm}$ de diámetro sin corrosión. Los resultados obtenidos sobre la sección de barras del mismo diámetro corroídas se aportan en las Figuras 7 y 9.

En la región exterior de la barra formada por martensita con microestructura de grano fino, la microdureza alcanza valores de $280 \mathrm{HV}$ que descienden hasta $227 \mathrm{HV}$ en el núcleo, formado por ferrita. La zona de transición presenta valores de microdureza intermedios entre los anteriores. La microdureza también resulta útil para confirmar el espesor de estas regiones, siendo el de la región exterior $2,5 \mathrm{~mm}$ y la de transición $2 \mathrm{~mm}$ en las barras de $20 \mathrm{~mm}$ de diámetro y de $1,5 \mathrm{~mm}$ en las de $16 \mathrm{~mm}$.

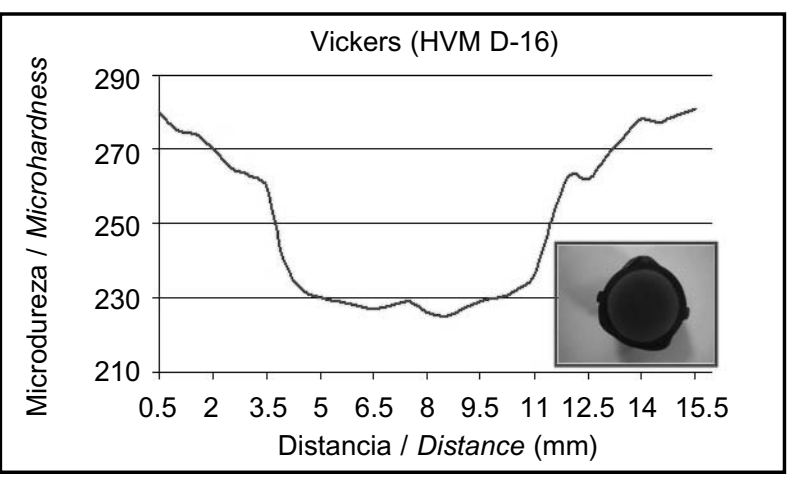

Figura 6. Resultados de microdureza Vickers de la sección de la barra de $16 \mathrm{~mm}$ de diámetro sin corrosión.

Figure 6. Vickers microhardness results in transversal section of a $16 \mathrm{~mm}$ diameter bar without corrosion.

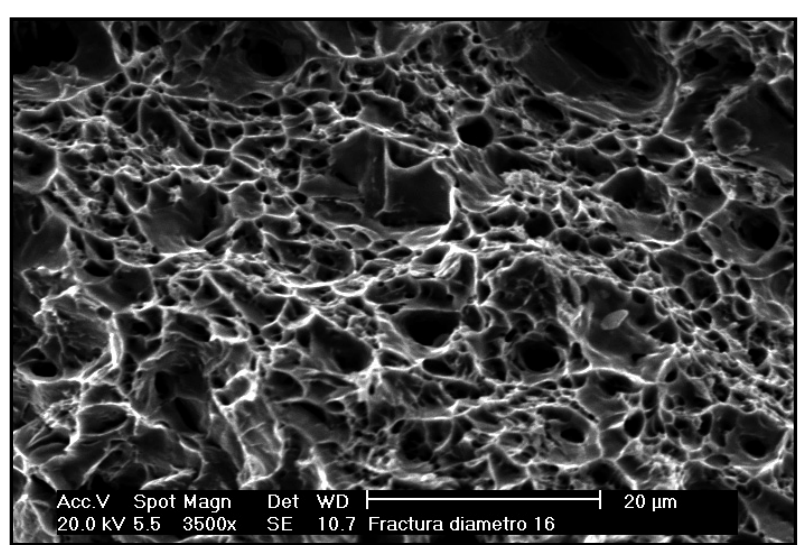

Figura 5. Micrografía de la fractura de la armadura de $16 \mathrm{~mm}$ corroída.

Figure 5. Micrography of the fracture area of a $16 \mathrm{~mm}$ diameter bar, which has undergone a corrosion process.

average section loss. Both micrographies offer the same aspect in the fracture: that is, coalesce of microvoids, which implies a ductile type fracture.

\subsection{Vickers microhardness}

Figures 6 and 8 show the Vickers microhardness results obtained for the transversal section of 16 and $20 \mathrm{~mm}$ bars without corrosion. The results obtained in section of corroded bars are shown in Figures 7 and 9.

At the bar exterior, composed of martensite with a fine granule microstructure, microhardness reach $280 \mathrm{HV}$ values, which lower to $227 \mathrm{HV}$ at the core, composed by ferrite. The transition zone presents micro hardness values in between the previous ones. Micro hardness is also useful to check the thickness of these areas: the external one being $2.5 \mathrm{~mm}$, the transition one $2 \mathrm{~mm}$ in $20 \mathrm{~mm}$ diameter bars, and of $1.5 \mathrm{~mm}$ in the $16 \mathrm{~mm}$ diameter ones.

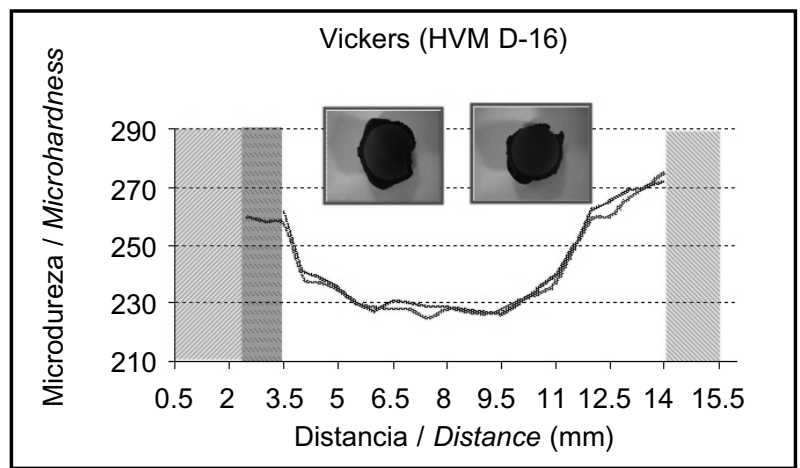

Figura 7. Resultados de microdureza Vickers de la sección de dos armaduras corroídas de $16 \mathrm{~mm}$ de diámetro.

Figure 7. Vickers microhardness results in transversal section of two corroded $16 \mathrm{~mm}$ diameter bars. 
La determinación de microdureza de las barras corroídas (Figuras 7 y 9) ha dado resultados de valor similar a los de la barra sin corroer. La pérdida de sección externa de estas últimas ha supuesto, dependiendo de la penetración del ataque por corrosión, la eliminación parcial o total de la martensita y de la zona de transición e incluso pérdidas de material correspondiente a la zona del comienzo del núcleo de la barra.

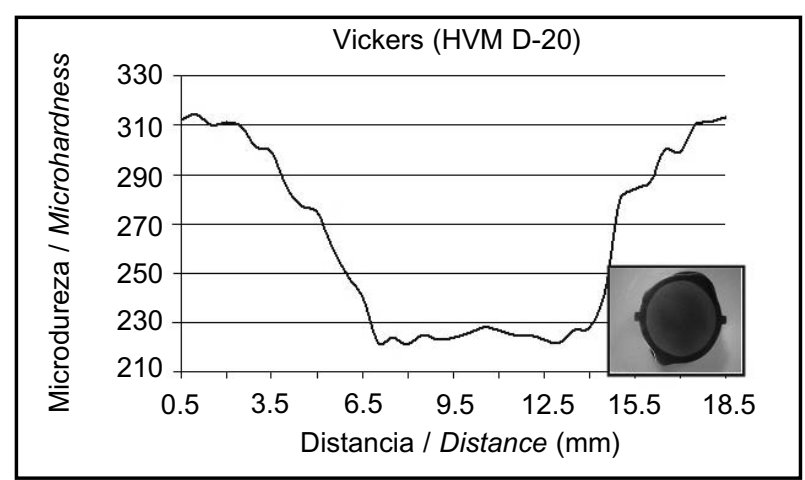

Figura 8. Resultados de microdureza de la sección de la barra de $20 \mathrm{~mm}$ de diámetro sin corrosión.

Figure 8. Microhardness results in the transversal section of an uncorroded $20 \mathrm{~mm}$ diameter bar.

\section{DISCUSIÓN}

Los valores obtenidos en las Tablas 2 y 3 sugieren que hasta penetraciones medias de corrosión de aproximadamente el $7,4 \%$ en barras de diámetro 16 o de $6,6 \%$ en barras de diámetro 20, podrían evaluarse EHA con armaduras corroídas utilizando como capacidad mecánica del acero el valor obtenido considerando únicamente su pérdida de sección. Si en estos casos la zona afectada por la corrosión no está situada en la zona de anclaje de las barras, únicamente se verán afectados los estados límites de servicio, con ligeros aumentos de flechas y aperturas de fisura en vigas de hormigón armado, pero no deberían verse afectados los estados límites últimos (16). Cuando la corrosión provoca penetraciones medias que superan los valores indicados anteriormente, las características mecánicas de las barras no cumplen las especificaciones de la Instrucción EHE, fundamentalmente por la disminución de los alargamientos, en este caso el análisis de la estructura cuando está situada en zona sísmica, requiere comprobaciones adicionales, incluso cuando la zona corroída no afecta al anclaje de las barras.

El incremento en el valor $f_{\mathrm{s}} / \mathrm{f}_{\mathrm{y}}$ según progresa el proceso de corrosión se puede explicar por el cambio que se produce en la relación entre los tipos de microestructura existentes en la barra cuando se produce el proceso de corrosión. En la corrosión, el material que se pierde pertenece fundamentalmente a la parte exterior de la sección, formada por martensita. Esto explica que disminuyan los
Microhardness results of corroded bars (Figures 7 and 9) have shown similar values to the ones of the uncorroded bar. The external section loss of the corroded bars, depending on the corrosion penetration attack, implies the total or partial elimination of martensite from the transition area, and even material loss corresponding to the area at the beginning of the specimen core.

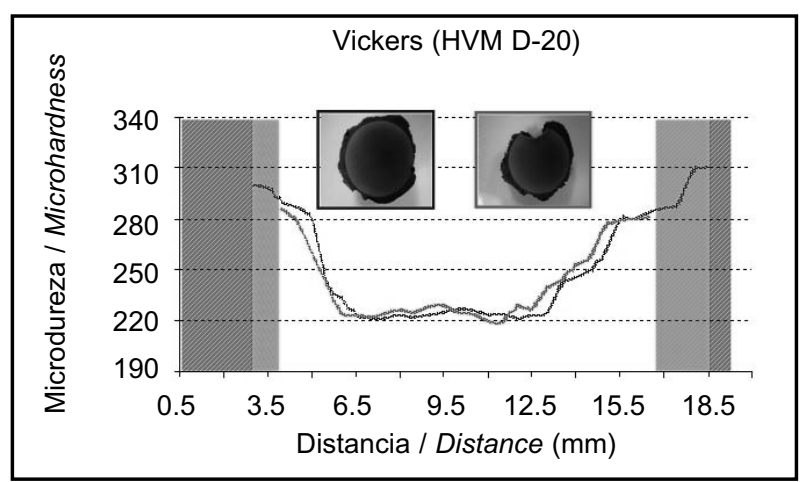

Figura 9. Resultados de microdureza Vickers de la sección de dos armaduras corroídas de $20 \mathrm{~mm}$ de diámetro.

Figure 9.Vickers microhardness results in the transversal section of two $20 \mathrm{~mm}$ diameter bars.

\section{DISCUSSION}

Results obtained, shown on Tables 2 and 3 suggest that average corrosion penetrations of approximately $7.4 \%$ for diameter 16 bars and 6.6\% for diameter 20 bars, with RCS corroded reinforcement could be assessed using as steel mechanical capacity the value obtained considering only the section loss. If in these cases, the corrosion affected area is not located in the anchoring of the bars, the limit service states will be affected with slight increases of deflection as well as fissure openings in the reinforced concrete beams might be expected. However, the ultimate state limits should not be affected (16). When corrosion penetrates more than in the previously stated values, the bar mechanical characteristics do not comply with EHE code specifications, mainly because of the elongation decrease. Moreover, the structure analysis needs additional checkings when it is located in a seismic area, even when the corroded area does not affect the bar anchoring.

The increase of the $f_{s} / f_{y}$ value as the corrosion process progresses can be explained by the change produced in the steel types mixed in the composition of the bar section when the corrosion process takes place. With the corrosion process, the material loss comes mainly form the external part of the section, composed of martensite. This is the reason for the decrease of the stress values within the 
valores de tensión ya que la sección perdida corresponde sólo a la martensita (de mayor resistencia que el núcleo de ferrita), pero aumenta $f_{s} / f_{y}$, ya que en el núcleo ese valor es mayor que en la periferia $(25,34,35)$.

Para poder cuantificar el efecto de la corrosión en la relación $\mathrm{f}_{\mathrm{s}} / \mathrm{f}_{\mathrm{y}}$ se ha realizado un análisis de regresión múltiple y se ha calculado el modelo bajo la hipótesis de que los errores son independientes y se distribuyen como una normal de media cero y varianza constante. En la Figura 10 se muestran los valores obtenidos para las 96 barras ensayadas junto a la recta de regresión. La recta de regresión obtenida para la relación $\mathrm{f}_{\mathrm{s}} / \mathrm{f}_{\mathrm{y}}$ y la cantidad de corrosión es la siguiente [1]: corrosion process, since the section loss belongs only to martensite (of higher strength than the ferrite core). However, the $f_{s} / f_{y}$ ratio increases in the core, where this value is greater than at the periphery $(25,34,35)$.

In order to quantify the corrosion effect in the $f_{s} / f_{y}$ ratio, an analysis of multiple regression has been performed and a model under the hypothesis that the failures are independent -and that they are distributed as a normal of mean 0 and constant variance- has been made. Figure 10 shows the values obtained for the 96 tested bars together with the regression line. The regression line obtained for the $f_{s} / f_{y}$ ratio and the corrosion quantity is the following [1]:

$$
f_{s} / f_{y}=(1+0.005 Q \text { corr }) f_{s 0} / f_{y 0}
$$

Donde $\mathrm{f}_{\mathrm{s} 0} / \mathrm{f}_{\mathrm{y} 0}$ representan los valores de la barra que no se ha corroído y Qcorr la pérdida porcentual de sección.

Tanto en el modelo como en la figura se puede apreciar cómo a medida que aumenta la pérdida de sección debida al proceso de corrosión, aumenta $\mathrm{f}_{\mathrm{s}} / \mathrm{f}_{\mathrm{y}}$.

La reducción de los valores correspondientes a deformación (Figura 3 y Tablas 2 y 3 ) se explica por el fenómeno de entalla provocado por las picaduras generadas por la corrosión, que hacen disminuir los alargamientos de la barra de forma considerable $(26,39)$.

El efecto de entalla se traduce en un aumento local del valor de las tensiones de tracción. En materiales dúctiles, como es el caso que nos ocupa, superada la fase elástica, se modifica la distribución de tensiones en la raíz de la entalla, tendiendo a homogeneizarse la distribución tensional, de modo que la resistencia de la barra no baja más allá de la debida a la pérdida de sección. Incluso podrían esperarse valores de carga de rotura por encima de los que se obtendrían contabilizando la sección realmente existente en la zona de la entalla si toda la sección fuese del mismo material (40) debido al efecto de
Where $f_{s 0} / f_{y 0}$ represent values which have not been corroded and Qcorr the section perceptual loss.

In both the model and the figure, it can be observed that as the section loss increases due to the corrosion process, the $f_{s} / f_{y}$ ratio increases.

The reduction of strain values, (Figure 3 and Tables 2 and 3), is caused by the necking phenomenon, produced in turn, by the corrosion pitting, which decrease the bar lengthening considerably $(26,39)$.

The necking effect appears as a local increase of the tensile stress. In ductile materials, as this case, once the yielding phase has been overcome, the stresses distribution at the root of the necking changes. The stresses distribution tends to homogenise in such a way that the bar strength does not decrease more than the section loss. Even, loading fracture values could exceed those when the section existing in the necking area would have been included in the calculation, if all the section were of the same material (40). This is so, because the adjacent sections to the necking area exert

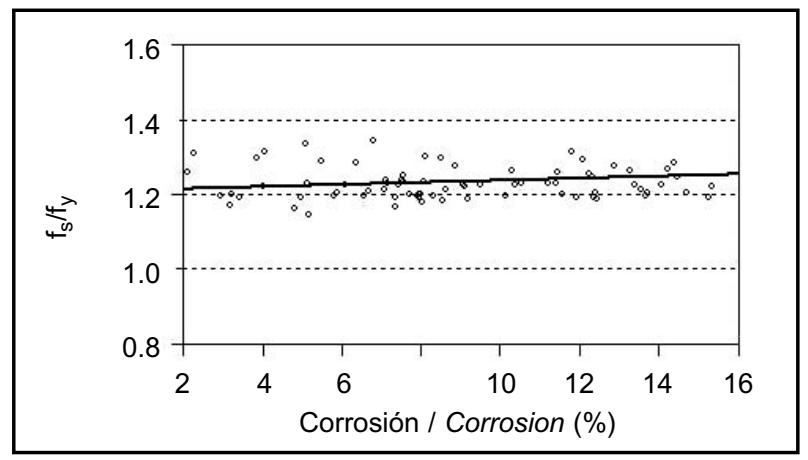

Figura 10. Efecto de la corrosión sobre $\mathrm{f}_{\mathrm{s}} / \mathrm{f}_{\mathrm{y}}$. Figure 10. Corrosion effect on $f_{s} / f_{y}$. 
confinamiento que ejercen las secciones adyacentes a las de la entalla que al ser más anchas impiden la contracción lateral de la parte más estrecha (41).

La consecuencia estructural más importante de la existencia de entallas es la disminución en los alargamientos experimentados por el acero durante el ensayo de tracción, la razón estriba en el sistema de tensiones triaxial simétrico que se produce en la zona inmediata a la entaIla, lo que dificulta la aparición de tensiones tangenciales en esa zona, necesarias para el desarrollo de la deformación plástica de esa zona.

El análisis de regresión múltiple efectuado proporciona los modelos para obtener $\varepsilon_{\max }$ en función del grado de corrosión (Figura 11). En este caso el efecto del diámetro es significativo, sin embargo, la interacción no lo es por lo que las rectas son paralelas. Las ecuaciones obtenidas para los diámetros 16 y 20 se indican en las expresiones [2] y [3], donde $Q_{\text {corr }}$ es la pérdida porcentual de sección: a struggling effect preventing the lateral contraction of the thinnest part (41).

The most important structural consequence of the necking is the decrease of the experimented lengthening in steel during the tensile strength test. The reason can be found in the symmetric triaxial stress system produced at the closest zone to the necking area. This then difficults the appearance of tangential stresses in this area, needed for the development of the yielding strain of this area.

The multiple regression analysis performed shows models to obtain $\varepsilon_{\max }$ regarding the corrosion level (Figure 11). In this case, the diameter effect is significant; however, the interaction is not, and therefore the lines are parallel. The respective obtained equations for diameters 16 and 20 are expressed in [2] and [3], where $Q_{c o r r}$ is the percentage section loss:

$$
\begin{gathered}
\varepsilon_{\max } \approx\left[1-0,02715 Q_{\text {corr }}\right] \varepsilon_{\max 0}(D-16) \\
\varepsilon_{\max } \approx\left[0,86-0,02715 Q_{\text {corr }}\right] \varepsilon_{\max 0}(D-20)
\end{gathered}
$$

Cuando se analiza el efecto de la corrosión sobre $\varepsilon_{\mathrm{u}, 5}$ (Figura 12), de nuevo el análisis de regresión conjunto da como resultado que hay dependencia del diámetro siendo las rectas de regresión paralelas. Las ecuaciones obtenidas para los diámetros 16 y 20 se indican en las expresiones [4] y [5], donde $Q_{c o r r}$ es la pérdida porcentual de sección:
When the corrosion effect on $\varepsilon_{u, 5}$ is analyzed (Figure 12), again the global regression analysis shows a dependency on diameter in the result, being the regression lines parallel. The equations obtained for diameters 16 and 20 are shown in expression [4] and [5], where where $Q_{\text {corr }}$ is the percentage section loss:

$$
\begin{aligned}
& \varepsilon_{\mathrm{u}, 5} \approx\left[0,9828-0,0229 Q_{\text {corr }}\right] \varepsilon_{\mathrm{u}, 50}(\mathrm{D}-16) \\
& \varepsilon_{\mathrm{u}, 5} \approx\left[0,8255-0,0229 Q_{\text {corr }}\right] . \varepsilon_{\mathrm{u}, 50}(\mathrm{D}-20)
\end{aligned}
$$

Tanto para $\varepsilon_{\max }$ como para $\varepsilon_{\mathrm{u}, 5}$, los análisis de regresión ponen de manifiesto que el efecto del diámetro es significativo, obteniéndose para el mismo grado de corrosión mayores disminuciones de alargamiento en las barras de diámetro superior.

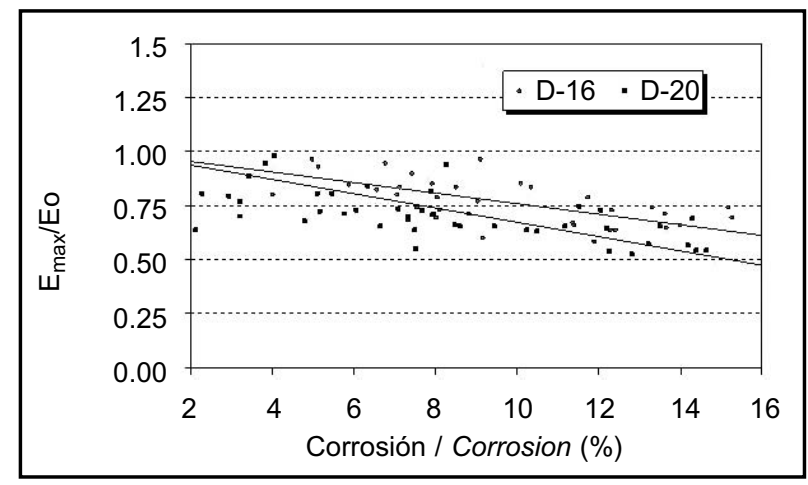

Figura 11. Efecto de la corrosión sobre $\varepsilon_{\max }$. Figure 11. Corrosion effect on $\varepsilon_{\max }$.
Both for $\varepsilon_{\max }$ and for $\varepsilon_{u, 5}$, the regression analyses highlights that the diameter effect is significant, obtaining for the same corrosion level, greater decreases in the lengthenings of greater diameter bars.

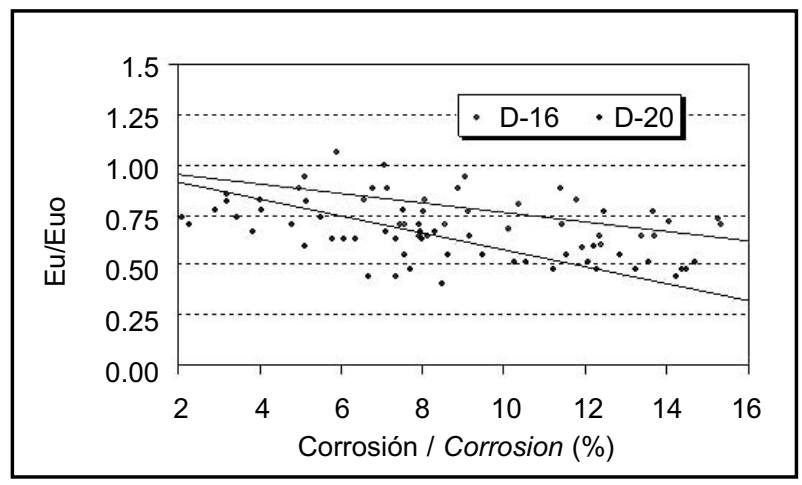

Figura 12. Efecto de la corrosión sobre $\varepsilon_{u, 50}$. Figure 12. Corrosion effect on $\varepsilon_{u, 5}$. 


\section{CONCLUSIONES}

- Niveles de corrosión que suponen una pérdida de sección media en las barras del 7,4\% (diámetro 16), o 6,6\% (diámetro 20) no implican variaciones en las propiedades mecánicas de las armaduras B500SD que impida considerarlas como de alta ductilidad.

- Cuando los niveles de corrosión en la armadura suponen pérdidas medias de sección del $11,4 \%$ (diámetro 16), o 8,5\% (diámetro 20), implican disminuciones en los alargamientos que impiden considerar las barras como de alta ductilidad.

- Incluso con niveles de corrosión tan bajos como los que suponen pérdidas de sección media del $4 \%$, se produce una variación cualitativa muy significativa en el aspecto de las curvas tensión-deformación, perdiéndose el escalón de cedencia y pasando a comportarse los aceros como deformados en frío.

- A medida que aumentan los niveles de corrosión se produce un incremento en el valor $f_{s} / f_{y}$. Este aumento se debe a que la corrosión afecta fundamentalmente a la martensita, que está situada en la corona exterior de la sección y posee un valor $d e \mathrm{f}_{\mathrm{s}} / \mathrm{f}_{\mathrm{y}}$ más reducido que la ferrita, situada en el núcleo y que prácticamente permanece intacta.

- Las picaduras originadas por la corrosión producen un efecto de entalla que originan disminuciones en los valores de alargamiento, mayores cuanto mayores son el diámetro y el nivel de corrosión de la barra.

\section{CONCLUSIONS}

- Corrosion levels which mean an average section loss of $7.4 \%$ in the diameter 16 bars and of $6.6 \%$ in the diameter 20 bars do not imply variations in the mechanical properties of the B500SD reinforcements, which can still be considered as high ductility ones.

- When the corrosion levels in the reinforcement show as a result average section losses of $11.4 \%$ (diameter 16) or $8.5 \%$ (diameter 20), the lengthening decreases hinder the consideration as high ductility bars.

- Even with quite low corrosion levels such as the ones producing an average section loss of $4 \%$, a highly significant qualitative variation in the stressstrain curves appears. Indeed, the yielding move is lost and the steel shows the behaviour of cold rolled steel.

- As the corrosion levels rise, an increase in the $f_{s} / f_{y}$ ratio is produced. This increase is due to the fact that corrosion mainly affects martensite, which is located at the external ring and has a smaller $f_{s} / f_{y}$ value than that of ferrite, located in the core and which is kept unaltered.

- Pitting corrosion produces a necking effect originating decreases in the strengthening values: these are greater when the diameter and bar corrosion are also greater.

\section{BIBLIOGRAFÍA / BIBLIOGRAPHY}

(1) CEB Design Guide Durable Concrete Structures. Thomas Telford Ltd (1992).

(2) Page, C. L.; Treadaway, K: Nature: 1982; 297 (5862): 109-115. http://dx.doi.org/10.1038/297109a0

(3) González, J. A.; Miranda J.: "Corrosión en las estructuras de hormigón armado: Fundamentos, medida, diagnosis y prevención". Consejo Superior de Investigaciones Científicas. Madrid (2007).

(4) Flaga, K.: "Advances in materials applied in civil engineering", Journal of Materials Processing Technology, vol. 106 (2000), pp. 173183. http://dx.doi.org/10.1016/S0924-0136(00)00611-7

(5) Broomfield, J. P.: "Life prediction of corrodible structures", NACE Symposium, Cambridge, Sept. (1991), Paper, 14.

(6) Cánovas, M. F.: Patología y terapéutica del hormigón armado, Ed. Dossat, S.A., Barcelona (1984), pp. 443-473.

(7) "Cathodic protection of reinforced concrete". Technical Report, no 36. The Concrete Society and NACE (1989).

(8) Tutti, K.: "Corrosion of steel in concrete", Swedish Cement and Concrete Research Institute, Stockholm (1982).

(9) González, J. A.; Feliú, S.; Rodríguez, P.: "Corrosión", 1997; 53: 65.

(10) Andrade, C.; Alonso, C.; Molina, M.: Mater. Struct. 1993; 26: 453-464. http://dx.doi.org/10.1007/BF02472805

(11) Alonso, C.; Andrade, C.; Rodríguez, J.; Casal, J.; García, M.: Hormigón y Acero (1994): 29.

(12) Fu, X.; Chung, D. D. L.: "Effects of water cement ratio, curing age, silica fume, polymer admixtures, steel surface treatments, and corrosion on bond between concrete and steel reinforcing bars". ACI Materials Journal, vol. 95, no 6 (1998), pp. 725-734.

(13) Calavera, J.; Delibes, A.; Izquierdo, J. M.; González, G.: "Influencia de la oxidación y de las manchas de mortero sobre la adherencia de armaduras de hormigón". MACSA, Estudio Monográfico, no 2 (1980).

(14) Perepérez, B.; Barberá, E.; Valcuende, M.; Alonso, A.; Gil, L.: "Durabilidad en ambiente marino de elementos lineales de hormigón armado bajo carga de servicio", pp. 163-172 GEHO-CEB (1997).

(15) CEB: "Assessment of concrete structures and design for up-grading (redesign)" (1983).

(16) Fuentes, A.: "Reinforced concrete after cracking". Oxford and IBH Publishing Co. Pvt. Ltd. New Delhi (1995), cap. II, 77-179.

(17) Cobo, A.: "Corrosión de armaduras en estructuras de hormigón armado: causas y procedimientos de rehabilitación". Fundación Escuela de la Edificación. Madrid (2001). 
(18) García, M. D.; Gutiérrez, J. P.; Rodríguez, J.: "Influencia de la corrosión sobre la adherencia acero-hormigón", Hormigón y Acero, no 210 (1998), pp. 23-44.

(19) Rodríguez, J.; Ortega, L.; Casal, J.; Vidal, M.: "Disminución de la adherencia entre hormigón y barras corrugadas debida a un proceso de corrosión", Hormigón y Acero, no 189 (1998), pp. 49-65.

(20) Fang, C.; Lundgren, K.; Chen, L.; Zhu, C.: "Corrosion influence on bond in reinforced concrete", Cement and Concrete Research, vol. 34 (2004), pp. 2159-2167. http://dx.doi.org/10.1016/j.cemconres.2004.04.006

(21) Fang, C.; Lundgren, K.; Plos, M.; Gylltoft, K.: "Bond behaviour of corroded reinforcing steel bars in concrete", Cement and Concrete Research, vol. 36 (2006), pp. 1931-1938. http://dx.doi.org/10.1016/j.cemconres.2006.05.008

(22) Shannag, M.; Al-Ateek, S. A.: "Flexural behaviour of strengthened concrete beams with corroding reinforcement", Construction and Building Materials, vol. 20 (2006), pp. 834-840. http://dx.doi.org/10.1016/j.conbuildmat.2005.01.059

(23) Rodríguez, J.; Ortega, L. M.; Casal, J.: "Load carrying capacity of concrete structures with corroded reinforcement", Construction and Building Materials, vol. 11 (1997), pp. 239-248. http://dx.doi.org/10.1016/S0950-0618(97)00043-3

(24) Du, Y. G.; Clark, L. A.; Chan, C.: "Residual capacity of corroded reinforcing bars", Magazine of Concrete Research, vol. 57 (2005), pp. 135-147. http://dx.doi.org/10.1680/macr.2005.57.3.135

(25) Apostolopoulos, C. A.; Papadopoulos, M. P.; Pantelakis, S. G.: "Tensile behaviour of corroded reinforcing steel bars BStt 500". Construction and Building Materials, vol. 20 (2006), pp. 782-789. http://dx.doi.org/10.1016/j.conbuildmat.2005.01.065

(26) Apostolopoulos, C. A.; Papadakis, V. G.: "Consequences of steel corrosion on the ductility properties of reinforcement bar", Construction and Building Materials, vol. 22 (2008), pp. 2316-2324. http://dx.doi.org/10.1016/j.conbuildmat.2007.10.006

(27) Moreno, E.; Cobo, A.; Cánovas, M. F.: "Ductilidad del acero de armar con diferentes grados de corrosión aplicando el criterio de acero equivalente", Mater. Construcc., vol. 57, no 286 (2007), pp. 5-17.

(28) Cobo, A.; Cánovas, M. F.; Moreno, E.: "Repercusión de la corrosión de la armadura en el comportamiento de estructuras de hormigón armado situadas en zona sísmica". Conpat. Quito (2007).

(29) Moreno, E.: "Corrosión de armaduras en estructuras de hormigón: estudio experimental de la variación de la ductilidad en armaduras corroídas aplicando el criterio de acero equivalente". Tesis Doctoral. Dpto. de Ciencia e Ingeniería de Materiales e Ingeniería Química. Universidad Carlos III de Madrid (2008).

(30) Cosenza, E.; Greco, C.; Manfredi, G.; "The concept of equivalent steel". Ductility Reinforcement, Comité Euro-international du Betón. Bollettin, n० 218. Lausanne (1993), pp. 163-184.

(31) Cosenza, E.; Greco, C.; Manfredi, G.: "An equivalent steel index in the Assessment of the ductility performances of the reinforcement". Ductility of Reinforced Concrete Structures, Comité Euro-international du Betón. Bollettin, n 242. Lausanne (1998), pp. 157-170.

(32) Creazza, G.; Russo, S.; "A new proposal for defining the ductility of concrete reinforcement steels by means of a single parameter". Ductility of Reinforced Concrete Structures, Comité Euro-international du Betón. Bollettin, nº 242. Lausanne (1998), pp. 171-181.

(33) Ortega, H.: "Estudio experimental de la influencia del tipo de acero en la capacidad de redistribución en losas de hormigón armado". Tesis doctoral. Universidad Politécnica de Madrid. Madrid (1998).

(34) Nikolau, J.; Papadimitriou: "Microstructures and mechanical properties after heating of reinforcing 500 MPa class weldable steels produced by various process (Tempcore, microalloyed with vanadium and work-hardened)", Construction and Buildings Materials, vol. 18 (2004), pp. 243-254. http://dx.doi.org/10.1016/j.conbuildmat.2004.01.001

(35) Bairán, J. M.; Rosa, J. C.; Marí, A.; Ortega, H.: "Efectos de la fabricación en rollo y desdoblado de armaduras pasivas de acero de alta ductilidad en sus prestaciones mecánicas". Congreso ACHE. Valencia (2008).

(36) Ministerio de Fomento: "Instrucción de Hormigón Estructural EHE-08". Madrid (2008).

(37) Andrade, C.; Alonso, C.: "On site measurements of corrosion rate of reinforcements", Construction and Buildings Materials, vol. 15 (2001), pp. 141-145. http://dx.doi.org/10.1016/S0950-0618(00)00063-5

(38) UNE-EN 10002-1 "Materiales metálicos. Ensayos de tracción. Parte1: Método de ensayo a temperatura ambiente". AENOR (2002).

(39) Cairos, J.; Plizzari, G. A.; Du, Y.; Law, D. W.; Franzoni, C.: "Mechanical properties of corrosion damaged reinforcement", ACI Materials Journal (2005), pp. 102, 256.

(40) Kuwamura, H.; Yamamoto, K.: "Ductile crack as trigger of brittle fracture in steel", Journal of Structural Engineering, vol. 123, n. 6 (1997), pp. 729-735.

(41) Feodosiev, V. I.: "Resistencia de Materiales". Ed. Mir. Moscú (1980). 